\title{
Retraction
}

\section{Retracted: Microalgae as a Renewable Source of Energy: A Niche Opportunity}

\author{
Journal of Renewable Energy
}

Received 5 April 2021; Accepted 5 April 2021; Published 28 June 2021

Copyright (C) 2021 Journal of Renewable Energy. This is an open access article distributed under the Creative Commons Attribution License, which permits unrestricted use, distribution, and reproduction in any medium, provided the original work is properly cited.

Journal of Renewable Energy has retracted the article titled "Microalgae as a Renewable Source of Energy: A Niche Opportunity" [1] due to significant text overlap identified with previously published articles [2,3].

The authors did not respond to communications regarding the concerns identified and did not respond to the notification of retraction. The article is therefore being retracted with the agreement of the editorial board.

\section{References}

[1] S. J. P. Jegathese and M. Farid, "Microalgae as a Renewable Source of Energy: A Niche Opportunity," Journal of Renewable Energy, vol. 2014, pp. 1-10, Article ID 430203, 2014.

[2] M. K. Lam and K. T. Lee, "Microalgae biofuels: a critical review of issues, problems and the way forward," Biotechnology Advances, vol. 30, no. 3, pp. 673-690, 2012.

[3] C. F. Murphy and D. T. Allen, "Energy-water nexus for mass cultivation of algae," Environmental Science \& Technology, vol. 45, no. 13, pp. 5861-5868, 2011. 